\title{
GEO-SPATIAL ANALYSIS AND RETAIL: BRINGING SATELLITE DATA AND CONSUMER DETAILS TO INDIAN RETAIL
}

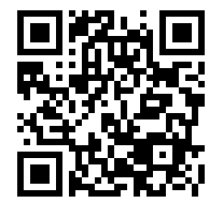

\author{
Nilesh Maurya ${ }^{1}{ }^{\square}$, Dr Vijay Singh Dahima ${ }^{2}$ \\ ${ }^{1}$ Director, Omega Capital, Mumbai, India \\ 2 Pro Vice Chancellor, Amity University Chhattisgarh, India
}

DOI: https://doi.org/10.29121/ijetmr.v7.i9.2020.753

Article Citation: Nilesh Maurya, and Dr Vijay Singh Dahima. (2020). GEO-SPATIAL ANALYSIS AND RETAIL: BRINGING SATELLITE DATA AND CONSUMER DETAILS TO INDIAN RETAIL. International Journal of Engineering Technologies and Management Research, 7(9), 47-51.

https://doi.org/10.29121/ijetmr.v7 i9.2020.753

Published Date: 08 September 2020

\section{Keywords:}

Geospatial Analysis

Geographic Information Systems

New Locations

Strategic Tool

\section{ABSTRACT}

Geographic Information Systems or to cover a broader aspect of GeoSpatial analysis, are changing the way businesses are done across the world. The number of satellites that was launched in the latter half of the previous century and all the investment that went into geographic and spatial is now bearing fruits trying to minimize the error rates in the business models. The "birds eye" is slowly becoming an important planning and strategic tool for management to take decisions. One industry that is reaping most of this innovation globally is the retail industry. Use of data in the retail industry is not new as retailers have been using a variety of data set from finding new locations to getting in more footfalls. They have been playing around data and draw insights to learn about customers and provide them with better service. But with changing times and retail business models, those data sets provide a limited scope to judge and make decisions. This is creating demand for new data sets that can provide access to deeper and more precise consumer-behaviour data. While the Indian market is witnessing a rapid change in retail consumer behaviour and newer and newer retail channels are being established, the geospatial analysis could be a big boon for businesses to clobber down their error rates as well as help them maximize their sales and generate a formidable customer base.

\section{INTRODUCTION}

\subsection{CHANGING FACE OF RETAIL IN INDIA}

The Indian retail industry is on a growth trajectory and is emerging to be one of the most dynamic and fastpaced sectors which are contributing to the countries growth. Over the last decade, the industry has seen the addition of several new players and channels and these additions have changed the consumer behaviour of the country on its head, bringing in various new components into the game. Today the Indian consumer is much more aware and has undergone various changes in his or behaviour with respect to attitude, motivation to buy, the propensity to spend, purchasing habits.

This change just doesn't stop at the point of sale but also has played an important role in framing the postpurchase behaviour. Few notable changes that have changed the Indian consumer market are

1) The Indian consumer of today has become more aware, demanding and conscious about the quality.

(C) 2020 The Author(s). This is an open access article distributed under the terms of the Creative Commons Attribution License, which permits unrestricted use, distribution, and reproduction in any medium, provided the original author and source are credited. 
Geo-Spatial Analysis and Retail: Bringing Satellite Data and Consumer Details to Indian Retail

2) The open economy has liberated the consumers and also has increased the competition thus shifting the products and strategies to more consumer oriented

3) The overall cost pressures on the manufacturers due to rising input cost which ultimately is squeezing the margin for the whole value chain including the retailers.

4) The E-commerce industry and it's discount offerings are disrupting the brick and mortar businesses

These changing consumer behaviours and the opportunity to grab its share in the growing retail industry has forced the business to adapt to changes and adopt strategies which were previously unheard of. And to build these strategies businesses are in hunt of data points that could help them identify. Also, these businesses are trying to be error-free in the decisions they make as rolling back doesn't lead to loss of money and time but also in today's world hampers the brand and goodwill of the business.

\section{UNDERSTANDING GEO-SPATIAL ANALYSIS}

In common terms, GeoSpatial Analysis is the use of data analytics- the technology and the tool- which draws inferences and outcomes for satellite databases and maps. These are computerized graphical systems way of analyzing data points which bring together the different streams of geography- physical and cultural- along with information technology and data analysis. While the geography of the location does fundamentally influence and binds together culture, lifestyle, business and society, it also has the power to answer many questions with respect to business and marketing questions and dilemmas.

Therefore, the tools such as the GIS and geospatial technologies which are an integral part of core geography, are turning out to be really useful for businesses adding value to the organization as well directly impacting the bottom line on the income statement. Geo-Spatial Analysis provides an electronic process that helps businesses in managing, integrating and analyzing massive amounts of geographic information by combining locational features with descriptive data in relatable database management. According to an official definition provided by Environmental System Research Institute (ESRI), a GIS is an organized collection of computer hardware, software, geographic data, and personnel designed to efficiently capture, store, update, manipulate, analyze, and display all forms of geographically referenced information

A Geographic Information System (GIS) comprises of a variety of components which include software, geographical data, hardware, geologist and data scientists. If a company plans to use geospatial technology and setups its GIS, only software will not do a job for them. While the location related database and digitalized maps are necessary, an objective of using the GIS, the qualified professionals and its amicable interactions with other departments of the company too is necessary.

Once the GIS is in place, it takes some time for data to collate for a particular location or for a particular exercise. Once a timeline-based data is in place with its mapping, the data scientist draws out relevant data points which can be used by managers to draw strategies around it.

\section{LITERATURE REVIEW}

GIS is a great information integration tool for decision makers which has a tremendous range of uses. With time it has become more powerful and gradually has become more economical, the more different types of information are available for incorporation. According to Chris Garthwaite, stores marketing administrator for Woolworths, the GIS system "is a very effective tool in understanding our local market, allowing us to respond to opportunities within key areas. It has been especially useful in understanding and answering to competitors' activity" (Reed, 1996). Ginger (1999) mentioned retailers' use of GIS technology for applications beyond mapping for store site selections. GIS also allows the retailer to track its competition in a region, as well as its customer base. Moloney (1992) emphasized that GIS allows retailers, and virtually any business organization, to go beyond data integration and map generation to explore relationships within a wide range of data. Smith and Webb (1997) demonstrated how the use of GIS can improve estimates of future retail space demand. Trubent et al. (2006) revealed that companies that have made large investments in GIS have achieved considerable cost savings. Robins (1993) indicated that due to decreasing costs and increasing PC power, more retailers are implementing geographic information systems (GIS). 
Nilesh Maurya, and Dr Vijay Singh Dahima

While a lot of authors across the globe have demonstrated how geospatial analysis is turning reasonable and becoming more and more useful, the adoption of the same is still slow and low. Many retailers have been slow to examine the possibilities of GISs (Simkin, 1985; Reynold, 1991). Goodchild (1991) mentioned that at a more instant level GIS suffers from all of the problems of a rapidly expanding industry. It lacks a clear focus, a set of institutional assemblies around which it might be organized. Despite progress has been made, the lack of clear consensus on these issues remains a significant impediment to the use of GIS in market analysis. Clarke (1993). Clarke and Rowley (1995) emphasized that despite some significant success stories, there has been only a slow diffusion of awareness of the benefits and request of site evaluation techniques in general, and the application of geographical information systems (GISs) in particular. Consequently, the dispersal of the benefits and applications has been remarkably slow, with location planning still being, by and large, the preserve of the major grocery chains, joined more recently by DIY retailers, department and variety store operators, pubs, banks and building societies (Clarke and Rowley, 1995).

\section{RISING DEMAND FOR GIS AND GEO-SPATIAL DATA}

Demand for GIS and geospatial is on the rise and this can be determined by the participation- over 15000 usersat the Esri's annual user conference in July 2018. Geospatial Media and Communications recently released a report titled GeoBuiz 2018 Report (previously known as The Global Geospatial Industry Outlook), which estimated that the geospatial industry is projected to reach US\$ 439.2 billion by 2020 , growing at a CAGR of $13.6 \%$. The report also went on to say that the economic impact created by geospatial technologies on the global GDP is $20 \%$ CAGR.

While these were the global numbers, MMK Sardana in his work called the An Overview of Geospatial Industry in India noted that at present, the size of the Indian geospatial industry is of the order of USD 4 billion which is growing annually at the rate of 12-15 per cent, and which may become a market of $\$ 20$ billion by 2025 .

\section{GEOSPATIAL AND RETAIL}

Currently, directly or indirectly, a lot of retailers are using data to draw various inferences from them. These data set includes

- Indoor movement and product placement analysis in Modern Trade

- Demographic and psychographic profiles of consumer groups in certain neighbourhoods, cities and regions;

- POS transaction analysis

- Loyalty data and rewards

- Customer Feedbacks- physical and social media

- Browsing habits

Underlying in all this data is the location intelligence which tells retailers where do their core customer position themselves as well as where they reside. Using further data tools and geo enrichment techniques, a retailer is currently trying to convert these customer addresses into insights of their tastes and devise strategies and communication which brings in more personalization to their target preference. Even though all outcome is based on the premise that a retailer's best customers often share behavioural and attitudinal traits, the results are still pretty accurate.

Considering all points, the fact remains that technology is changing the game for modern businesses by rewriting the rules which dint even existed a decade ago and geospatial and location analysis is definitely one of them. ESRI considers that the future success of retail will be determined to a large degree by the competitive advantages of investing in and implementing smart technology like GIS.

For a brick and mortar store retailer, his profitability at a given location is directly dependent on the revenue potential vis a vis his lease rentals for that store. A poorly located store does have a huge impact on the retailers bottom-line. An incorrect decision of localization culminates into a series of sequential errors in the concept of the marketing mix for that location. Out of the four P's if the P for Place is wrong or inappropriate the function of the other three P's gets destabilized and collapses the complete marketing plan.

As the business environment is turning more and more competitive, retailers are trying to grab every advantage to acquire and retain customers. Parallel to this, they are also taking decisions of locating profitable sites as well as 
Geo-Spatial Analysis and Retail: Bringing Satellite Data and Consumer Details to Indian Retail

staying abreast with the competitors. In the Indian context, a GIS and geospatial technology can defiantly provide some advantages to retailers which may be included but are not restricted to

- Helping in creating smarter Go-t- Market strategies by combining location and census data.

- Analyse new suburbs and cities for expansion rollouts based on the formats the business operates

- Investigate the existing stores and maybe tweak their business model formats which may including deciding to have a store in the mall or on a high street

- Examing the right income group for its products and examine the customer traffic in and around that area

- Examining the consumer behaviour of an existing store in the shortlisted area to have a pulse of that market

- Analyzing customer movement and whether customers moving from a particular location

- Analyzing change in trends created by crucial infrastructure developments in and around the store area

- Accounting and analyzing Sales pattern and trends with respect to the location it is in.

- Trying to match the distribution network match with consumer location.

- Identification of a series of existing locations that resemble the proposed location.

- Compilation of maps and reports that highlight the crucial information about a potential site in a consistent and comparable manner, which shows changes in customer behaviour through major censuses.

- Measuring the impact of new store opening and relocations along with the competitive acquisition

- Performing GAP analysis of the location

- Integrating consumer data in CRM and develop insights.

- Calculating sales potential of a location based on the Huff Model - an interaction model measuring the probabilities of consumers at each origin location patronizing a new store instead of other stores

\section{CASE: HOW GIS IS ADDING HUL'S PROJECT SHAKTIMAN}

In 2001, Hindustan Unilever, with the idea to empower women in the hinterland by creating livelihood opportunities and take its product to "media-dark" zones in rural India launched Project Shakti. Under this Project, HUL trained thousands of women in villages across India to develop an entrepreneurial mindset and make them financially independent. These women entrepreneurs (called Shakti Ammas) were trained on basic tenets of distribution management and familiarisation with the Company's products.

In 2010, Project Shakti expanded its operations and included men (Shaktimaan as part of its distribution network. These Shaktimaans were usually husbands of Shakti Ammas. Under this model HUL gave, Shaktimaans (male members), a bicycle, to be able to service villages within a 3 to $5 \mathrm{~km}$ radius and hence cover a larger area than a woman, Shakti amma, can cover on foot. In revenue terms, an average a Shaktiman approximately got double the business of a Shakti amma and helped HUL penetrate to deeper areas.

While the project was a great distribution and corporate social responsibility case, it also wrote an amazing chapter as to how GIS could be used in retail. HUL according to data available, used GIS to mapped and tracked villages around the 'Shakti' families and allocated Shaktimaan's accordingly so that they could cover 5-6 villages and maximize its reach.

With bringing in GIS to great use along with project management skills in rural marketing, HUL executed Project Shakti with great success and has penetrated villages in 16 states. In terms of the magnitude of impact companies reach was to over 1.3 lakh villages across India with the help with over 80000 Shakti Ammas

\section{CONCLUSION}

For retail businesses, it is well understood the core and the soul of the business is the right location. This not only brings prominence to the business but also allows the business to be at the right place, at the right time with the right product. The location, for a store, also stands important as it gives a long-term competitive edge to the store which cannot be translated to numbers. While globally a lot of big brands are making GIS and geospatial an integral 
part of this decision-making process beyond just location scouting, it's now time for Indian companies to invest and built in this technology so they can capture the dynamic consumer behaviours and sentiments.

\section{SOURCES OF FUNDING}

None.

\section{CONFLICT OF INTEREST}

None.

\section{ACKNOWLEDGMENT}

None.

\section{REFERENCES}

[1] Mckinsey and Co report "Who's shopping where? The power of geospatial analytics in omnichannel retail" https://www.mckinsey.com/industries/retail/our-insights/whos-shopping-where-the-power-ofgeospatial-analytics-in-omnichannel-retail

[2] ESRI report on "GIS Solutions for Retail- Understand Your Business from a New Perspective" https://www.esri.com/library/brochures/pdfs/gis-for-retail.pdf

[3] www.retailouchpoints.com article "Using Location Intelligence to Boost Retail Efforts" https://www.retailtouchpoints.com/features/executive-viewpoints/using-location-intelligence-to-boostretail-efforts

[4] FICCI report "Empowering India through Geospatial Technologies" http://ficci.in/spdocument/20195/FICCI-GT-Empowering-India-through-Geospatial-Technologies.pdf

[5] www.IBEF.org -Retail Industry https://www.ibef.org/industry/retail-india/infographic

[6] A T Kearney's Report, http://www.atkearney.in/consumer-products-retail/global-retail-development-index

[7] HUL Project Shakti https://www.hul.co.in/news/news-and-features/2018/more-power-to-rural-women.html

[8] Duffy, D. (1999). Mapping your success. [Online] Available: http://www.cio.com.au/article/69135/mapping_your_success

[9] Burrough, P.A. (1985). Principles of GIS for Land Resources Assessment. Clarendon Press.

[10] Christopher, M., McDonald, M., Wills, G. (1980). Introducing Marketing. Pan, London.

[11] Clarke, M. (1993). Mapping out retail direction. International Journal of Retail \& Distribution Management, Vol. 21, Issue 2, pp. 36-38.

[12] Euromonitor International. (2007). China and India surge forward in the Asia-Pacific Retail industry. August, [Online] http://www.euromonitor.com/China_and_India_surge_forward_in_Asia_Pacific_Retail_industry

[13] Fickes, M. (2006). Matching trends to technology. Chain Store Age, May, Vol.82, Issue 5, pp.138.

[14] Goodchild, M.F. (1991). Geographic information systems. Journal of Retailing, spring, Vol. 67, No. 1, pp.3-15.

[15] Goodchild, M.F. (1991). Geographic information systems. Journal of Retailing, spring, Vol. 67, No. 1, pp.3-15.

[16] Hess, R.L., Rubin, R.S., and West, L.A. (2004). Geographic information systems as a marketing information system technology. Decision Support Systems, Vol. 38, Issue 2, pp. 197-212.

[17] Reed, D. (1996). Streets ahead. Marketing Week, May, Vol. 19, Issue 8, pp. 69-71.

[18] Robins, G. (1993). Retail GIS use growing. Stores, Jan, Vol. 75, Issue 1, pp. 44- 47.

[19] SBL Geomatics. (2008). GIS in India and its Importance. [Online] Available: http://www.prlog.org/10154283-gis-in-india-and-its-importance.html

[20] Trubint, N., Ljubomir, O. and Nebojša, B. (2006). Determining an optimal retail location by using GIS. Yugoslav Journal of Operations Research, Vol.16, No. 2, pp. 253-264. 